\title{
A study on reproductive endocrinology of white- tailed deer (Odocoileus virginianus) by immunoassay of steroid hormones metabolytes in feces
}

\begin{abstract}
Summary
The objective of this study was carried out a documentary review on studies about monitoring endocrine activity of white-tailed deer (Odocoileus virginianus) by immunoassay of feces to diagnose ovarian cycle activity, sex allocation and pregnancy diagnostics was conducted. The results indicated that it is feasible to monitor reproductive endocrine activity by estimating gonadic steroid metabolytes in urine and feces, although the results are not consistent due to level variations of metabolytes in feces and also due to the pregnancy and sex allocation diagnostics efficiency. Several factors determine this variability, therefore, it is necessary to optimize technologies and /or test strategies to standardize sampling methods, to obtain more reliable results.
\end{abstract}

Keywords: white-tailed deer, steroid metabolytes, endocrinology studies, noninvasive methods
Volume 2 Issue 4 - 2018

\author{
Rubén Cornelio Montes-Perez \\ Facultad de Medicina Veterinaria y Zootecnia, Universidad \\ Autonoma de Yucatan, Mexico
}

Correspondence: Rubén Cornelio Montes Perez, Facultad de Medicina Veterinaria y Zootecnia, Universidad Autonoma de Yucata, Carretera Mérida-Xmatkuil km I5.5, CP. 973I5. Merida, Yucatan, Mexico, Tel 52 9992621918,

Email ruben_montes_p@correo.hotmail.com

Received: July 06, 2018 | Published: July 19, 2018

\section{Introduction}

Reproduction of white-tailed deer (Odocoileus virgininianus) can occur all year round in various South American countries; the highest breeding months range between February and May. Most births occur from July to November. In Canada, the breeding months are between October and December (less than 70 days). ${ }^{1}$ In the United States and Mexico, the mating occurs from October to January, and births appear between April and September of the following year. The females are seasonally polyestrous, with an estrous cycle duration between 26 and 28 days, estrous lasts between 18 and 24 h, pregnancy lasts $200 \pm 5$ days, generally give birth one or two fawns, the reproductive capacity begins at about 1,5 years of age. ${ }^{1,2}$ In the male deer, the months of low reproductive activity are from February to August in the North hemisphere of the American continent, when testosterone levels are below $4 \mathrm{nmol} / \mathrm{l}$, which means that the hypothalamus-hypophysisgonad axis activity is low; but from September to January, the testosterone levels in blood reach values from 8 to near $40 \mathrm{nmol} / 1,{ }^{1}$ characteristic of high reproductive activity and therefore of a complete axis functioning, which induces the characteristic changes such as high seminal production, mating behavior, fights to assemble and preserve the harem, muscle and antler development.

The ovarian cycle of the females is endocrinologically represented by two phases: follicular and luteous. In the first phase, follicular growth takes place, where levels of blood progesterone descend to values lower than $1,0 \mathrm{ng} / \mathrm{ml}$; in the second phase, progesterone increases due to ovulation and the formation of one or more corpora lutea, in this stage the progesterone reaches levels around $5,1 \mathrm{ng} / \mathrm{ml}^{3}{ }^{3}$ If the white-tailed female deer (WTD) does not conceive during the reproductive season, it will remain with basal levels of progesterone during the no reproductive season, otherwise, it will maintain high levels of blood progesterone, due to the presence of corpus luteum ${ }^{3,4}$ reported blood progesterone values in female WTD lower than 0,25 $\mathrm{ng} / \mathrm{ml}$ at days 2 and 5 of the estrous cycle, $0,80 \mathrm{ng} / \mathrm{ml}$ at day $9,2,46$ $\mathrm{ng} / \mathrm{ml}$ at day $12,1,23 \mathrm{ng} / \mathrm{ml}$ at day $16,1,43 \mathrm{ng} / \mathrm{ml}$ at day $19,0,45 \mathrm{ng} /$ $\mathrm{ml}$ to day 23 and undetectable values at day 26 , which is the average time of the estrous cycle. They concluded that the levels, pattern of changes and individual variation of blood progestin of the white tailed female are similar to those reported for domestic sheep.

\section{Material and methods}

Reports on endocrinological studies by immunoassay of steroids hormones metabolytes in feces of white-tailed deer (Odocoileus virginianus) in USA, Mexico and others countries, were analized and discussed.

\section{Results and discussion}

Endocrine studies in Mexico regarding white-tailed deer are limited, mainly due to the jittery nature of this species, fast speed and ability to jump $2 \mathrm{~m}$ fences, to suffer dislocations and fractures of long bones and joints, ${ }^{5}$ the risk of losing animals due to capture induced myopathy, which can lead to late or acute death. ${ }^{6}$ On order to avoid the previous events and other stress related issues, it is necessary to conduct endocrine studies by noninvasive methods, from urine or feces samples. ${ }^{7}$ The bioregulators that conform the hypothalamuspituitary-gonad axis, are composed of polypeptides $(\mathrm{GnRH})$, glycoproteins (FSH/LH) and steroids (blood progestin, androgens and estrogens). GnRH and LH undergo catabolism of their polypeptide chains by release into the blood stream, in addition to having a pulsing and episodic secretion pattern, in other words, by high concentration waves but in relatively short periods (6 to $8 \mathrm{~h}$ ). Nevertheless, the steroidal gonadic hormones, have different a catalytic process, through reduction and conjugation processes with sulfates and glucuronides that allow them to conserve the cyclopentane-perhydrophenanthrene ring and some radicals from the androstane, estrane or pregnane families, which can be detected in urine and feces. ${ }^{8}$ From the gonadic steroids, the hormone that works as an indicator of the ovarian cycle, ovulation and therefore a functional corpus luteum, due to its chemical, physiological qualities, and permanence throughout 
the estrous cycle properties in females, is the blood progesterone; nevertheless, in white-tailed deer the monitoring of this hormone to assess the reproductive activity with the conventional methods is not practical, due to the need of holding the animals to take blood samples.

The viable alternative is to monitor by noninvasive methods such as the hormonal estimation of progesterone, namely their metabolytes in urine and feces. ${ }^{9}$ From the types of urinary and fecal samples, the last one offers advantages because of its simplicity, both to collect it and to store it. In urine samples the estimation must be adjusted based on the amount of creatinine, in addition it must be extracted from the ground where it was deposited. The fecal sample does not require additional treatment and it can be directly stored in a freezer for periods no longer than 4 months. ${ }^{7}$ The quantification of progesterone in urine and feces of white-tailed deer have been performed by radioimmunoassay (RIA), and enzyme-immunoassay (ELISA). ${ }^{10,11}$ Mercado et al., ${ }^{12}$ reported that the measurement of fecal progesterone in white-tailed females during the estrous period showed values fluctuating between 0,02 to $369 \mathrm{ng} / \mathrm{g}$; significant variations in the luteous phase $(139,57$ to $307,55 \mathrm{ng} / \mathrm{g}$ ) and pregnant (64 to 189,86 $\mathrm{ng} / \mathrm{g}$ ) were detected compared to the anestrus ( 0 to $0,51 \mathrm{hg} / \mathrm{g}$ ) during the months of September to May of the following year. Kapke et al. ${ }^{13}$ reported values of fecal progesterone from 5 to $40 \mathrm{ng} / \mathrm{g}$ and of its metabolyte, fecal pregnanediol from 0 to $55 \mu \mathrm{g} / \mathrm{g}$ throughout the estrous cycle, being high during the luteous phase, where the values are greater to those quantified by RIA for blood progesterone (7 ng/ $\mathrm{ml}$ ) by Knox et al., ${ }^{10}$ and even greater than the $2.46 \mathrm{ng} / \mathrm{ml}$ reported by Kirkpatrick et al., ${ }^{5}$ during the estrous cycle monitoring. However, the results of fecal glucuronide pregnanediol to assign pregnancy in white-tailed females have been variable, Walter et al. ${ }^{14}$ mention that there were no significant differences between pregnant females $(3,44 \pm 0,8 \mu \mathrm{g} / \mathrm{g})$ and non-pregnant females $(3,01 \pm 0,65 \mu \mathrm{g} / \mathrm{g})$. In the spring of 1998 and spring of 1999, pregnant females showed levels of $5,38 \pm 5.07 \mu \mathrm{g} / \mathrm{g}$ and the non-pregnant of $4.89 \pm 5.31 \mu \mathrm{g} / \mathrm{g}$, but Kapke et al., ${ }^{13}$ reported that the fecal pregnanediol levels are consistently high during pregnancy ( 20 to $84,8 \mu \mathrm{g} / \mathrm{g}$ ), but at the end of pregnancy the values drop to $30 \mu \mathrm{g} / \mathrm{g} .{ }^{14}$

Cervera-Hernandez et al., ${ }^{15}$ reported that it is possible to diagnose pregnancy of white-tailed females by estimating progesterone levels in feces, the results indicated that the efficiency of pregnancy diagnosis in the non-breeding season was $77,78 \%$; the predictive value of the positive diagnosis was $75 \%$, and the negative was $80 \%$, which means that accuracy is greater for diagnosing non pregnancy, although the correlation between blood and fecal progesterone is low (0.37) but significant $(\mathrm{P}<0.01)$, with individual variations between 0.104 to 0.99 . Therefore, it is necessary to validate the technique in larger deer populations in captivity, since non pregnancy could be diagnosed efficiently with months in advance before the birth season.

In the case of sex allocation in this species, the reports are scarce ${ }^{16}$ report an efficiency of $73.75 \%$ in quantifying fecal progesterone by means of diluted extract 1:20 with cut-off value of $9000 \mathrm{ng} / \mathrm{g}$ and of $77,5 \%$ when measuring Testosterone at $1: 2$ dilutions, in the nonmating season with a cut-off value of $95 \mathrm{ng} / \mathrm{g}$. However, in the mating season, in fecal progesterone diluted to $1: 2$ the efficiency increases to $78,75 \%$ with cut-off value of $4800 \mathrm{ng} / \mathrm{g}$. This same work reported that when assigning sex by indexes, the efficiency was $77.5 \%$ with the ratio progesterone / testosterone in dilution 1:20/1:2 respectively with cut-off value 3.8 , and in the same relation but with dilution 1.2/1: 2 respectively but with a cutoff value of 2.9 in the non-breeding season. In the breeding season, the efficiency was of $68,75 \%$ in relation to the progesterone/testosterone with dilution of 1:2 /1: 20 respectively and with cut-off value of 7.9 .

Montes-Perez et al., ${ }^{17}$ reported that when the feces are subject to weathering, in a warm sub humid climate during the periods of 0 (T1), 10 (T2), 20 (T3) and 30 (T4) days, the indexes that presented/ displayed greater efficiency to assign sex in WTD in the non-breeding season were estradiol/testosterone with $77,5 \%$, al $\mathrm{T} 1$, testosterone/ estradiol with $75 \%$ at $\mathrm{T} 2$, testosterone/progesterone with efficiency of $70 \%$ at $\mathrm{T} 3$, and the relation estradiol/progesterone with $62,5 \%$ at T4. In the breeding season, the efficiency was of $84,6 \%$ for the progesterone/estradiol relation at T1, 75\% efficiency with the relation testosterone/progesterone at T2, 86,8\% efficiency in the progesterone/ testosterone relation at T3, and 84.8 efficiency in the relation estradiol/ testosterone at T4. In summary, the highest efficiency values were obtained in the breeding season for all the weathered treatments, in different steroid and dilution combinations of fecal steroid extract. Some of the identified factors that cause variability in the steroid hormone metabolytes estimation results in urine and feces are those reported by, ${ }^{7}$ who mention that the variation is influenced by the fiber content in the diet; the diet quality factor is important in young animals,$^{18}$ showed that in winter, animals subject to low quality diets produce higher levels of fecal glucocorticoids than animals that consume control diets (higher nutrient levels), therefore are subject to nutritional stress. Similarly, the fecal testosterone levels $(148,0 \pm 5,0$ $\mathrm{ng} / \mathrm{g}$ ) are greater in animals with poor diet than in those that consume control diets $(130,4 \pm 4,8 \mathrm{ng} / \mathrm{g})(\mathrm{P}<0.01)$; on the other hand, the scale difference reported in the steroid concentrations is not consistent for the value comparison ${ }^{19}$ reported that the progesterone secretion and release in blood that comes from adrenal glands, which raise total blood progesterone levels when the animals are subject to stress ${ }^{20,21}$ showed differences between estimates because of variability between standards or calibrators of immunoassays, proposed interlaboratory standardization of calibrators to generate comparable, accurate and precise results. They also reported that immunoassays for steroid extraction have greater variability than direct assays due to the effect of solvent and different extraction percentages..$^{15}$ demonstrated broad individual variation in the endocrine response to stress, based on the occurrence of animals that endure more stress than others. Lopez and $^{16}$ demonstrated the effect of fecal steroid extract dilution on the estimated metabolyte levels. Additionally, the effects of the time and weathering in feces, on the sex allocation efficiency by estimation of steroidal metabolyte levels were demonstrated by. ${ }^{17}$

\section{Conclusion}

It is possible to monitor endocrine reproductive activity in whitetailed deer as well as to diagnose pregnancy and to assign sex by estimating progestin, androgen and estrogen metabolytes levels using immunoassays such as ELISA or RIA. However, results are variable due to various factors, some still undetermined. Therefore, it is necessary to carry out more research to optimize these technologies and/or to test strategies for standardizing sampling methods which will produce accuracy and precise estimations.

\section{Acknowledgements}

None.

\section{Conflict of interests}

The author states there is no conflict of interests. 


\section{References}

1. Pérez GO. Patrones de secreción de progesterona, estrógenos y testosterona en venado cola blanca veracruzano (Odocoileus virginianus veraecrucis) durante un ciclo anual en la zona centro del estado de Veracruz. Tesis de Maestro en Ciencia Animal. Universidad Veracruzana. Veracruz, Ver. 2014. 70 p.

2. Galindo LC, Weber M. El venado de la sierra madre occidental Ecología, manejo y conservación. Ediciones Culturales S.A. de C.V. México. 1998. p. 272.

3. Plotka ED, Seal US, Verme LJ, et al. Reproductive steroids in deer. III Luteinizing hormone, estradiol and progesterone around estrus. Biology of Reproduction. 1980;22(3):576-581.

4. Plotka ED, Seal US, Verme LJ, et al. Reproductive steroids in white tailed-deer. IV. Origin of progesterone during pregnancy. Biology of Reproduction. 1982;26(2):258-262.

5. Kirkpatrick RL, Vogelsang RW, Warren RJ. Plasma progestin levels of female white-tailed deer during the estrous cycle. The Virginia Journal of Science. 1976;27:46.

6. Clark RK, Jessup DA. Captura e inmovilización de animales silvestres. VIII Curso Taller Internacional: Técnicas aplicadas a la conservación y manejo de fauna silvestre. U.S. Fish and Wildlife Service, Colegio de Postgraduados, Programa de Ganadería. Montecillos, Estado de México. 2001. p. 139-284.

7. Valdespino C, Martínez-Mota R, García-Feria LM, et al. Evaluación de eventos reproductivos y estrés fisiológico en vertebrados silvestres a partir de sus excretas: evolución de una metodología no invasiva. Acta Zoológica Mexicana. 2007;23(3):151-180.

8. KEGG: Pathway: Steroid hormone biosynthesis - Reference pathway. Sin año.

9. Riveros FJL. Métodos de estudio de la reproducción en hembras de ungulados silvestres. Revista Electrónica de Veterinaria. 2010;11:1-28.

10. Knox WM, Miller KV, Collins DC, et al. Serum and urinary levels of reproductive hormones associated with the estrous cycle in white-tailed deer (Odocoileus virginianus). Zoobiology. 1992;11(2):121-131.

11. Luévano MAO, Mercado RMM. Efecto de los factores ambientales en la concentración de progesterona en heces fecales de hembra de venado cola blanca Odocoileus virginianus en Zacatecas. Memorias del XXI Congreso Nacional de Zoología 2013.146. Universidad Autónoma de
Aguascalientes. 2013

12. Mercado RM, Ramos SSE, Blancas MM. Concentración de progesterona en heces fecales de hembra de venado cola blanca (Odocoileus virginianus) durante el ciclo reproductivo en cautiverio. $5^{\text {a }}$. Jornadas de Investigación Universidad Autónoma de Zacatecas. Trabajo: BIO/UBE-12/028. 2001. P. 1-10.

13. Kapke AC, Arcese P, Ziegler TE, et al. Estradiol and progesterone metabolite concentrations in white tailed-deer (Odocoileus virginianus) feces. Journal of Zoo and Wildlife Medicine. 1999;30(3):361-371.

14. Walter DW, Pekins PJ, Rutberg AT, et al. Evaluation of immunocontraceptive adjuvants, titers and fecal pregnancy indicators in free-ranging white tailed-deer. Wildlife Society Bulletin. 2002;30(3):908-914.

15. Cervera-Hernández $\mathrm{P}$, Montes-Pérez RC, Victoria-Arceo F, et al Método no invasivo de diagnóstico de gestación en venadas Odocoileus virginianus. Revista Ciencia en Desarrollo. 2015;6(1):9-16.

16. López-Cobá EH, Montes-Pérez RC. Valoración de metabolitos de testosterona, progesterona y estrógeno en excretas de venado cola blanca (Odocoileus virginianus) como método para determinar el sexo. Revista Mexicana de Biodiversidad. 2016;87:180-186.

17. Montes-Pérez R, Montes-Cruz F, Góngora-Chan C, et al. Asignación del sexo en Odocoileus virginianus por análisis de excretas sometidas a intemperie. Abanico Veterinario. 2016;6(2):13-21.

18. Taillon J, Côté SD. Are faecal hormone levels linked to Winter, diet quality and social rank in young ungulates? An experiment with whitetailed deer (Odocoileus virginianus) fawns. Behavioral Ecology and Sociobiology. 2008;62:159-1600.

19. Plotka E, Seal U, Verme L. The adrenal gland in white-tailed deer: A significance source of progesterone. Journal of Wildlife Management. $1983 ; 47: 38-44$

20. Pilo A, Zucchelli GC, Chiesa ME. Components of variance analysis of data produced in a national quality-control survey of radioimmunoassay of rhuroxin, triiodothyronine, thyrotropin, prolactin and progesterone. Clinical Chemistry. 1986;32(1):171-174.

21. Pilo A, Pilo A, Zucchelli GC. Improvement in the quality of estradiol, progesterone and testosterone RIAs: Evaluation of the between-kit and within-kit contributes to the overall variability. Clinical Chemistry. 1986;32(6):1183. 